\title{
Bishops and Pins in Jorge Ibargüengoitia
}

\author{
Pedro Serrano ${ }^{1}$
}

The Mexican Jorge Ibargüengoitia $(1928-1983)$ is one of those often misunderstood contemporary writers whose work is adequately interpreted only when placed within a larger aesthetic context. A peculiar presence in the landscape of Latin American literature, he was widely recognized and cherished since his first plays, and he has his novels constantly republished; nevertheless, his literary significance has not been able to take a central place in the official canon. His writings generally cover different periods of Mexican history but his most important titles had to do with the present-day Mexico than with the author's own time. What happens in an apparent tragicomedy or caricature within his accomplished novels expresses a tragic and terrible reality. Likewise, his so called "absurdities" always reflect dark realities, exposing the absurdity of corrupt rulers, authoritarian impunity and rampant privilege resulting from the actions of those in power. The overlapping of reality and fiction in Ibargüengoitia's narrative is central to its destabilizing power and insight, his characters posses an amazing freedom of movement and their humanization definitely opposes caricature. It is through the deceptive light of humor that they show the naked violence and misfortune of Mexican reality. [Article copies available for a fee from The Transformative Studies Institute. E-mail address: journal@transformativestudies.org Website: http://www.transformativestudies.org (O2019 by The Transformative Studies Institute. All rights reserved.]

KEYWORDS: Latin American Fiction, Mexican Literature, Violence, Humor, Absurd, History, Actuality.

Jorge Ibargüengoitia has a peculiar presence in the landscape of Mexican literature. He is a beloved author, widely recognized and cherished since his first plays, and his novels are constantly republished. However, and after more than thirty years, his literary significance in Mexican Literature has not been able to take a central place in the literary canon. I

\footnotetext{
${ }^{1}$ Pedro Serrano. Biography available at end of article. Address correspondence to: Pedro Serrano; e-mail: pedrosco@gmail.com.
} 